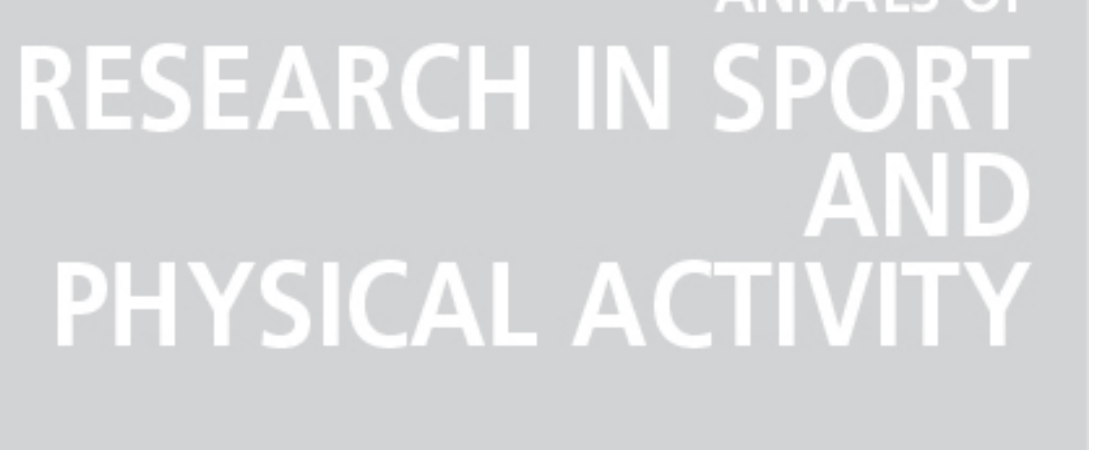

\title{
Growth hormone response to acute exercise: effects of chronic training and acid- base status
}

\author{
Autor(es): Hammarstrom, D.
}

Publicado por: Imprensa da Universidade de Coimbra

URL persistente:

URI:http://hdl.handle.net/10316.2/3370

DOI:

DOI:http://dx.doi.org/10.14195/2182-7087_2_6

Accessed : $\quad$ 26-Apr-2023 07:15:57

A navegação consulta e descarregamento dos títulos inseridos nas Bibliotecas Digitais UC Digitalis, UC Pombalina e UC Impactum, pressupõem a aceitação plena e sem reservas dos Termos e Condições de Uso destas Bibliotecas Digitais, disponíveis em https://digitalis.uc.pt/pt-pt/termos.

Conforme exposto nos referidos Termos e Condições de Uso, o descarregamento de títulos de acesso restrito requer uma licença válida de autorização devendo o utilizador aceder ao(s) documento(s) a partir de um endereço de IP da instituição detentora da supramencionada licença.

Ao utilizador é apenas permitido o descarregamento para uso pessoal, pelo que o emprego do(s) título(s) descarregado(s) para outro fim, designadamente comercial, carece de autorização do respetivo autor ou editor da obra.

Na medida em que todas as obras da UC Digitalis se encontram protegidas pelo Código do Direito de Autor e Direitos Conexos e demais legislação aplicável, toda a cópia, parcial ou total, deste documento, nos casos em que é legalmente admitida, deverá conter ou fazer-se acompanhar por este aviso. 
(2) 2011

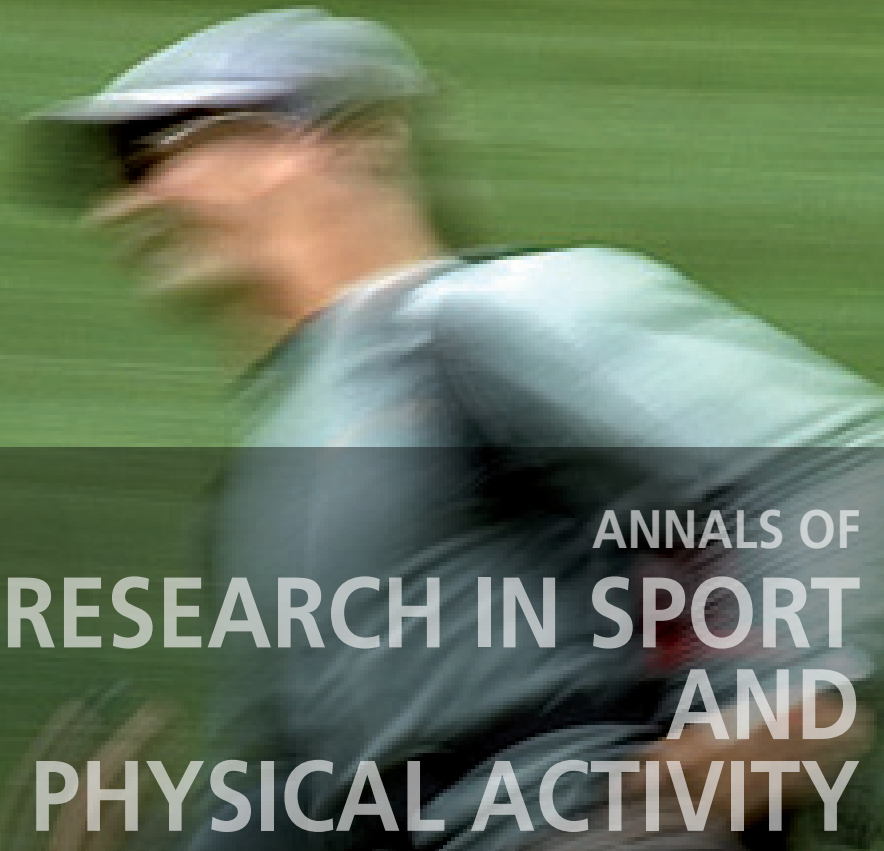

FACULDADE DE

CIÊNCIAS DO

DESPORTO E

EDUCAÇÃO FÍSICA DA UNIVERSIDADE DE COIMBRA

IMPRENSA

DA UNIVERISDADE

DE COIMBRA 
2・SPORT TRAINING

GROWTH HORMONE RESPONSE TO ACUTE EXERCISE: EFFECTS OF CHRONIC TRAINING AND ACID-BASE STATUS 


\section{PURPOSE}

The study investigated whether $\left[\mathrm{H}^{+}\right]$-dependent growth hormone $(\mathrm{GH})$ response to exercise is affected by chronic alteration of acid-base status during training. The study also investigated GH secretion during acute exercise in relation to adaptation to endurance training.

\section{METHODS}

21 healthy subjects (age, $24.4 \pm 2.5 \mathrm{yr}$; height, $180.9 \pm 5.8 \mathrm{~cm}$; weight, $78.8 \pm 11.6 \mathrm{~kg}$; $\left.\mathrm{VO}_{2 \text { peak' }} 48.5 \pm 1.7 \mathrm{ml} \cdot \mathrm{kg}^{-1} \cdot \mathrm{min}^{-1}\right)$ underwent a six week leg-cycle training. During training subjects were supplemented with either $\mathrm{NaHCO}_{3} ;\left(0.4 \mathrm{mg} \cdot \mathrm{kg}^{-1}\right)$ or placebo. GH response to high-intensity exercise ( $8 \times 2$-min, 1-min rest at $90 \%$ of PPO) was evaluated before and after the training during leg-cycling (under influence of $\mathrm{NaHCO}_{3}^{-}$) and arm-cycling.

\section{RESULTS}

Exercise increased $\mathrm{GH}$ levels in both groups $(\mathrm{P}<0.05)$ with no effects from $\mathrm{NaHCO}_{3}$. Pre-training GH response to leg-cycle exercise was inversely related to the improvement in LT $(r=-0.580, P<0.05)$. GH response to exercise was positively correlated to relative exercise intensity and increase in $\left[\mathrm{H}^{+}\right]$pre-training $(r=0.477$ and 0.560 , respectively, $\mathrm{P}<0.05)$ but not post-training.

\section{CONCLUSION}

Thus, this novel finding suggests a potential role of the GH-IGF axis in the adaptive response to endurance training.

\footnotetext{
1 University of Dalarna, Sweden; e-mail: dha@du.se.
} 